Journal of Indonesian Economy and Business

Volume 36, Number 3, 2021, 255 - 271

\title{
THE STUDY OF MANGROVE ECOSYSTEMS' SERVICES VALUATION IN SEMARANG CITY
}

\author{
Tito Aditya Perdana ${ }^{1 *}$, Febrianur Ibnu Fitroh Sukono Putra ${ }^{1}$, and Risanda Alirastra \\ Budiantoro ${ }^{1}$ \\ ${ }^{1}$ Department of Management, Faculty of Economics and Business, Universitas Dian Nuswantoro, \\ Semarang, 50131, Indonesia
}

\begin{tabular}{|c|c|}
\hline ABSTRACT & ARTICLE INFO \\
\hline $\begin{array}{l}\text { Introduction/Main Objectives: This study estimates how much } \\
\text { economic value will be lost from contact activities within the coastal } \\
\text { areas in the research location. Background Problems: The area of } \\
\text { Semarang City has flood and tidal problems, the damage to the mangrove } \\
\text { forests in Semarang City began with the boom in shrimp farming } \\
\text { between } 1980 \text { and } 1990 \text {. Hopefully, this valuation can provide an } \\
\text { overview of the current health of the ecosystem and become the basis for } \\
\text { a mangrove management strategy in the future. Novelty: The novelty of } \\
\text { this study is that it uses a sharper satellite (Image Pleades Resolution } 0.5 \text { m) to } \\
\text { calculate the mangrove area in the research location. Research Methods: This } \\
\text { research uses a total economic valuation, an estimation of the mangrove's } \\
\text { carbon stock and heavy metals, the replacement cost to prevent tidal } \\
\text { flooding, and the willingness to pay. Findings/Results: We find that the } \\
\text { existing economic value in the study area is very large and should be } \\
\text { preserved for conservation. Conclusion: The environment cannot } \\
\text { produce something instantly, but it needs to be preserved as a balance to } \\
\text { nature. }\end{array}$ & $\begin{array}{l}\text { Article information: } \\
\text { Received } 20 \text { September } \\
\text { 2020. Received in revised } \\
\text { version } 16 \text { Augustus } \\
\text { 2021. Accepted } 6 \\
\text { September } 2021 \\
\text { Keywords: } \\
\text { willingness to pay, } \\
\text { contingent valuation, } \\
\text { environmental } \\
\text { valuation, mangrove } \\
\text { JEL Code: } \\
\text { Q26, Q51 }\end{array}$ \\
\hline
\end{tabular}

\footnotetext{
* Corresponding Author at Department of Management, Faculty of Economics and Business, Universitas Dian Nuswantoro, Jalan Nakula I, No. 5 - 11, Semarang 50131, Indonesia.

E-mail address: titoadityap92@ dsn.dinus.ac.id / titoadityap92@gmail.com (author\#1), fbr10@dsn.dinus.ac.id (author\#2), risanda.abe@dsn.dinus.ac.id (author\#3)
} 


\section{INTRODUCTION}

The coastal area has strategic meaning because it is an intermediate area between the terrestrial and marine ecosystems, and potentially has very rich natural resources and environmental services. The wealth of these resources creates an attraction for various parties to utilize the resources and for various agencies to regulate their utilization. Indonesia's wealth of coastal resources, including around 17,500 large and small islands, are surrounded by tropical coastal ecosystems, such as mangrove forests, coral reefs, seagrass beds, along with the biological and non-biological resources contained therein. However, the wealth of these coastal resources is starting to be damaged (IUCN \& Mangrove Action Project, 2007).

Mangrove forests and the protectors of tropical coastlines are among the many ecosystems that will be lost to climate change unless adaptive management strategies are established. Many people's livelihoods will also be affected. Mangrove ecosystems act as spawning areas for fish and invertebrate species that then live on coral reefs and in the pelagic zone, and they control the chemical aspects of the water in coastal areas. Mangrove ecosystems provide food, fuel, and other things for humans. These ecosystems become the front row buffer systems in the case of critical conditions, such as storms and other extreme events. (WWF, 2009).

The complex network of mangrove roots can help reduce wave energy, limit erosion, and protect coastal communities from the destructive forces of tropical storms. In addition to the mangrove ecosystem being part of an important source of seafood for consumption, mangroves also play an important role in global climate dynamics. On average, mangroves store around 1,000 tonnes of carbon per hectare in biomass and the substrate, making the mangrove ecosystem a carbon-rich ecosystem (Duke $\mathrm{N}$ et. al., 2014). Despite their value, mangrove ecosystems are among the most threatened on the planet. This is caused by land conversion activities for cultivation and agriculture, coastal development, waste, and overexploitation. Mangrove areas are becoming smaller and more fragmented, so that the consequences of mangrove degradation will be more severe for the welfare of coastal communities in developing countries, especially where people rely heavily on mangrove goods and services for their daily needs and livelihoods (Duke $\mathrm{N}$ et al., 2014). Given the significant economic value of the coast and mangrove forests, this area has become the target of various exploitation activities (IUCN \& Mangrove Action Project, 2007).

At this time, the level of environmental damage that threatens coastal areas is increasing. According to the results of a study conducted by Central Java Province's Bappeda in 2007, it was found that the mangrove area in Central Java was 10,786 ha, of which $96.9 \%$ had suffered damage. The area of mangroves continues to be degraded, so the results of a study on mangroves in 2014 only obtained a vegetation cover area of 5,381.15 ha (Department of Marine Affairs and Fisheries, Central Java Province, 2016).

As the home to forty-two million Indonesians, the population of the north coast (Pantura) of Java continues to increase every year, so the need for land increases. The three agglomerations on the coast of Java contribute $20 \%$ of Indonesia's GDP, which is USD 186 billion or the equivalent of 2,700 trillion rupiah. Conditions in the field show that several locations in the three agglomeration areas experienced abrasion, causing a high level of land loss, as happened in Demak Regency, where abrasion has eroded 476 ha of land. Abrasion also has the potential to cause ecosystem degradation in the Javanese Pantura region (Ministry of National 
Development Planning / BAPPENAS, 2019). In particular, the development of the coastal area of the Javanese Pantura coast, as the backbone of the national economy, still faces several challenges. The development of this area is threatened by rising sea levels, the threat of tidal flooding, and the threat of land subsidence. Based on BNPB data, the amount of losses due to tidal flooding that occurs annually in the Pantura of Java reaches billions of rupiah. If the handling of these problems is not immediately addressed, parts of the Javanese Pantura may be permanently inundated. Therefore, by looking at all the problems that occur in Java's coastal areas, it is necessary to carry out an integrated and sustainable coastal management program (Ministry of National Development Planning/ BAPPENAS, 2019).

For the case of Semarang City, the average land subsidence is $4.37 \pm 4 \mathrm{~cm} /$ year (Islam et. al., 2017). The areas that experienced the highest average decline were in the districts of Genuk, Pedurungan, and North Semarang, with values of $10.35 \pm 1.02 \mathrm{~cm} /$ year, $8.31 \pm 2.36 \mathrm{~cm} /$ year, and $8.23 \pm 1$, respectively., $5.8 \mathrm{~cm} /$ year. Besides, there is a correlation between land subsidence and the expansion of the tidal flood area and its stratigraphic arrangement. The correlation with tidal flooding is indicated by the expansion of the tidal flood area into the area that experienced the highest decline in Semarang.

Furthermore, the coast of Semarang City has also been affected by abrasion. One of the areas experiencing severe abrasion is the western part of Semarang Beach which includes the Tugu and West Semarang districts. The problems that often occur in these areas are quite severe, especially regarding the decline in land use due to coastal abrasion and seawater inundation in the pond area. The coastal damage occurred along approximately $2.25 \mathrm{~km}$ of Tugu District covering Mangunharjo Village, Mangkang
Wetan Village, Randugarut Village, Karanganyar Village, Tugurejo Village, and approximately $0.5 \mathrm{~km}$ in West Semarang District, in Tambakharjo Village (Fajrin et al., 2016).

Semarang has flood and tidal problems which often hamper the activities of its residents. The flood disasters paralyze the community's socio-economic activities, resulting in the malfunctioning of existing urban infrastructure, such as airports and stations. Flooding and tidal inundation is getting more serious and increasing in extent and depth over time. Coastal Semarang often faces tidal flooding which can occur during the rainy season, or during the dry season. This flooding often occurs in northern Semarang. Flood and tidal inundation in northern Semarang has also been exacerbated by land subsidence. Land subsidence is a serious matter, especially if it occurs in coastal areas. This condition is because coastal areas are very vulnerable to environmental pressures, both from land and from the ocean (Suripin, \& Syafrudin, 2015).

According to Safitri et. al., (2019), geographic processes in the coastal areas of Semarang are very dynamic, one of which is caused by damage to the mangrove forests. The destruction of the mangrove forests in Semarang City began with the boom in shrimp farming between 1980 and 1990. The community was given the capital to illegally control the mangrove forest area and open it for shrimp ponds.

In connection with the important role of mangrove forests, and as part of the restoration and conservation efforts, information is needed on the valuation of the mangrove ecosystem's services on the coast of Semarang City, which includes the supporting services, providers, regulators, and culture. This valuation can provide an overview of the current condition of the ecosystem and form the basis for future mangrove management strategies. 
This mangrove ecosystem monitoring activity intends to address these challenges by promoting ecosystem-based solutions in Semarang, specifically for its coastal areas. The Nusantara Nature Conservation Foundation (YKAN), in collaboration with relevant stakeholders, initiated an alliance called the Mangrove Ecosystem Restoration Alliances (MERA), a national platform involving multi-stakeholders to achieve common goals by building an integrated plan from all the parties. This has been based on scientific certainty to reduce the vulnerability of coastal communities, natural resources and vital state assets, as well as the development of climate change mitigation and adaptation efforts in coastal areas.

In the context of realizing integrated management efforts on the coast of Semarang, especially in terms of ecosystem degradation and its recovery efforts, one of the main strategies/ activities developed is the development of databases/information and scientific developments in the biophysical aspect. Monitoring of mangrove ecosystems needs to be carried out as a basis for developing appropriate designs and approaches in the preparation of plans and designs for mangrove ecosystems' restoration and studies on the valuation of the mangrove ecosystems' services will be able to provide an overview of the importance of the mangrove ecosystems on the coast of Semarang.

The implementation of mangrove ecosystem monitoring activities is focused on the coastal areas of Semarang City, Central Java Province. The following 10 coastal villages in Semarang City were observed, namely: Mangunharjo Village, Mangkang Kulon Village, Mangkang Wetan Village, Randugarut Village, Karanganyar Village, Tugurejo Village, Tambakharjo Village, Terboyo Kulon Village, Terboyo Wetan Village, Trimulyo Village.

\section{LITERATURE REVIEW}

\section{Total Economic Value}

Shathirathai (2003) has stated that the economic valuation method involves the monetary measurement of changes in a person's welfare caused by changes in the environmental quality. This measurement value is known as the total economic value (TEV). Akhmad Fauzi (2004) defined economic value as a measurement of the maximum amount of goods and services someone wants to sacrifice to obtain other goods and services. This definition implies that the economic value of a good and service is measured by the sum of the willingness to pay (WTP) of many individuals for the intended goods or services. Economic valuation is about measuring the preferences of people. The results of such evaluations are expressed in terms of monetary values, as a means of discovering the secret of the people's preferences.

According to Freeman III (2014), TEV is the sum of the economic value based on use (use value) and the economic value based on non-use (non-use value). The use value (UV) consists of the value of the direct use (direct use value), the economic value of the indirect use (indirect use value), and an option value (option value). Meanwhile, the non-use value (NUV) consists of two value components, namely the bequest value and the existence value.

Barton (1994) presents several methodological approaches to valuing ecosystems/ resources based on the above typologies. Most of the approaches used are based on the cost approach because the benefit approach is relatively difficult to predict. Some of the most well-known methodologies are effect on production (EOP) or production analysis and benefitcost analysis or benefit and cost analysis, where benefits are represented by the revenue from production. 


\section{Contingent Valuation Method (CVM)}

The contingent valuation method (CVM) was first proposed as a theory by S.V CiriacyWantrup in (1968) to obtain the market value of non-traded goods. Since then CVM has been used by many people. CVM was implemented by Davis (1963) in his research on hunting behavior in Miami. This approach became popular only around the mid-1970s when the United States government adopted this approach to natural resource studies. This approach is called a contingent method because in practice the information obtained is highly dependent on the hypothesis that is built. Technically, this CVM approach can be done in two ways, the first is through experimental techniques with simulations and games and the second is through survey techniques.

\section{Willingness to Pay}

WTP or willingness to pay is an individual's willingness to pay for an environmental condition, or an assessment of the natural resources and natural services to improve the environmental quality. In WTP, it is calculated how much the aggregate ability of each individual or society is to pay or spend money to improve the environmental conditions to reach the desired conditions. WTP is a potential use value of natural resources and environmental services (Hanley and Spash, 1996).

According to Fauzi (2004), WTP is the maximum amount a person is willing to pay to avoid a decline in something. WTP is defined as the maximum amount of money that a person can pay, so that indifference is between the option to pay for a change in something, for example, environmental improvement, or rejecting the change and spending the money on something else.

\section{The Method, Data, and Analysis}

\section{A. Mangrove Vegetation Data}

Tree volume analysis was conducted to determine the size of the existing mangrove wood volume. To obtain the wood volume, the diameter and total height data are required and in this study, the stem volume was limited without calculating the crown (branches, twigs, leaves, flowers, and fruits).

$$
\mathrm{V}=1 / 4 \times \pi \times \mathrm{d}^{2} \times \mathrm{t} \times \mathrm{f}
$$

Where: $\quad \mathrm{V}=$ Volume $\left(\mathrm{m}^{3}\right)$

$\pi=$ Constant (3.14)

$\mathrm{d}=$ The diameter of the tree trunk

$\mathrm{t}=$ Tree height $(\mathrm{m})$

$\mathrm{f}=$ Number of tree shape (0.6)

The obtained tree volume will describe the condition of the mangrove forest on each hectare. Besides that, it can also be used as an initial calculation of the potential economic value of the mangrove wood. The stand value can be determined by calculating the cubication of wood produced, multiplied by the selling price per $\mathrm{m} 3$, multiplied by the area then subtracting the operational costs.

\section{B. Data on Estimation of Mangrove Carbon Stocks and Heavy Metals}

The mangrove's biomass calculation is generated from the diameter breast height (DBH) data of a tree using allometric equations that refer to several scientific publications. Meanwhile, the estimated carbon content in the sediment was analyzed in the laboratory using the LECO brand CHNS Truspect Analysis tool with \% C in dry weight, and then the sample was refined.

The potential carbon stock in the aboveground and below-ground biomass is based on grams of wet weight (gbb) and grams of dry weight (gbk) converted to grams of carbon per unit area (gbb m-2, gbk m-2, and $\mathrm{gC} \mathrm{m}-2$ ). The 
carbon concentration in organic matter is around 47\% (Eggleston et al, 2006).

Table 1. Allometric Model of several Mangrove Types.

\begin{tabular}{lll}
\hline $\begin{array}{c}\text { Mangrove } \\
\text { Species }\end{array}$ & Allometric Model & \multicolumn{1}{c}{ Source } \\
\hline $\begin{array}{l}\text { Avicennia } \\
\text { marina }\end{array}$ & $\mathrm{B}=0.1848 * \mathrm{D}^{2.3524}$ & $\begin{array}{l}\text { Dharmawan and } \\
\text { Siregar, 2008 }\end{array}$ \\
$\begin{array}{l}\text { Rhizophora } \\
\text { apiculata }\end{array}$ & $\mathrm{B}=0.043 * \mathrm{D}^{2.63}$ & Amira, 2008 \\
$\begin{array}{l}\text { Rhizophora } \\
\text { mucronata }\end{array}$ & $\mathrm{B}=0.1466 * \mathrm{D}^{2.3136}$ & Dharmawan, \\
$\begin{array}{l}\text { Information: } \\
\text { B }=\text { Biomass }(\mathrm{Kg}) ; \\
\text { breast height }(\mathrm{cm}) .\end{array}$ & $\mathrm{D}=$ Diameter at \\
\end{tabular}

The estimated amount of carbon stored per component is calculated by multiplying the total weight of the biomass by the carbon concentration. The dry weight of the carbon storage component in a certain area is converted to a carbon value by the following calculation:

$$
\begin{aligned}
& \text { Carbon } \\
& \text { Stock }
\end{aligned}=\begin{aligned}
& \text { Biomass } \\
& \text { per area }
\end{aligned} \times 0.47(\text { IPCC, 2006) }
$$

The initial process of calculating the carbon content in sediments requires bulk density data which refers to Kauffman \& Donato (2012) with the formula:

$$
\begin{aligned}
& \text { Bulk } \\
& \text { Density }
\end{aligned}=\frac{\text { Dry Weight of sample }(\text { gram })}{\text { Sample Volume }(\mathrm{cm} 3)}
$$

Furthermore, the calculation of carbon in sediment uses the following formula (SNI, 2011):

$$
\begin{aligned}
& \begin{array}{l}
\text { Sediment } \\
\text { carbon } \\
(\mathrm{gr} \mathrm{cm}-2)
\end{array} \\
& \text { bulk density } \\
& (\mathrm{gr} \mathrm{cm}-3)
\end{aligned} \times \begin{gathered}
\text { depth interval } \\
(\mathrm{cm}) \times \% \mathrm{C}
\end{gathered}
$$

Mangrove Biomass Analysis:

1. Mangrove biomass determination used an allometric model for each species.

2. The value of $\rho=$ wood density $(\mathrm{gr} / \mathrm{cm} 2)$ refers to the website:

http://db.worldagroforestry.org/.
Carbon Stock Analysis:

1. IPCC (2006) states that carbon stocks are estimated from biomass, following the rule that $47 \%$ of biomass is carbon. So that the estimated amount of carbon stored is by multiplying 0.47 by the biomass.

2. After calculating the carbon stock in grams, the carbon reserve is converted into tonnes. According to the Indonesian National Standard (2011) the conversion of carbon stocks is into units of tonnes per hectare.

Heavy Metal Analysis

1. The heavy metal analysis was measured using an atomic absorption spectrometry (AAS) tool.

\section{Flood Prevention Rob}

The calculation of the valuation of mangrove ecosystem services as the preventor of tidal flooding is carried out through a replacement cost approach based on data on the value of community losses. Another approach is to look at the production value that is affected in an area, such as rice fields and aquaculture areas.

The tidal flood inundation map used in the calculation of this valuation value uses Scenario 4 data with a specification of inundation height reaching $168.38 \mathrm{~cm}$ and a total inundation area of 2,691.37 ha. Selection of Scenario 4 (there are scenarios 1 to 6), was based on the fact that the inundation area is the largest compared to the other scenarios. Then, the map data for Scenario 4 was overlaid with the coastal map of Semarang City, to determine the area of tidal flood inundation in the categories of settlements, ponds, rice fields, and industrial areas.

The calculation of the value of losses for settlements refers to Karunia's research (2017) in the settlement of Genuk District, Semarang City. Meanwhile, the calculation for ponds and paddy fields refers to the productivity value of each 
area as a producer of milkfish and rice (BPS, 2019). Then the calculation of industrial areas was done using assumptions by looking at the cost of coastal protection's development in the form of wave breakers (APO) along the coastline (industrial areas only).

\section{Mangrove Ecosystem Services Valuation Data}

Identification of the benefits and functions associated with mangrove forests involves dividing the economic value of a mangrove forest resource into its use values and non-use values. The use value is divided into two, namely the direct value and indirect value. The non-use value is divided into three, which comprise the value of choice benefits, existence benefit values, and inheritance benefits (Suzana et. al., 2011).

The analysis method used in this research includes the economic valuation of mangrove forests, fisheries productivity, and the economic value of coastal lands.

\section{(1) Direct Use Value (DUV)}

The direct use value (DUV) is the benefit that can be obtained directly from the mangrove forest's ecosystem, for example, mangrove wood, fishery resources, food, tourism, and health/medicine (Barton, 1994).

$$
\begin{aligned}
\mathrm{ML}= & \alpha+\beta \mathrm{MLHi}+\beta \mathrm{MLPi}+ \\
& \beta \mathrm{MLTi}+\beta \mathrm{MLWi}+\ldots
\end{aligned}
$$

ML =Direct use value.

MLHi =Direct use value of forestry products.

MLPi $=$ Direct use value of fishery products.

MLTi $=$ Direct use value of ponds.

MLWi=Direct use value as an attractive flora \& fauna habitat for tourism, estimated to be equivalent to the rupiah value spent by tourists at the place. (It is assumed that the distribution of benefits is evenly distributed throughout the mangrove forest area).

(2) Indirect Use Value (IUV)

The indirect use value (IUV) is the benefits obtained from an ecosystem indirectly, for example, mangrove forests as a deterrent to seawater interference, spawning areas, care and foraging (spawning ground, nursery ground, and feeding ground), as a flood prevention tool, windbreaks, and several other ecological functions (Barton, 1994).

$\mathrm{MTL}=\mathrm{MTLe}+\mathrm{MTLb}, \ldots$

MTLe = Indirect use value from the ecological mangrove ecosystem, which is estimated based on the replacement cost of the building value of the breakwater.

$\mathrm{MTLb}=$ Indirect use value from biology (as a place for providing organic feed for aquatic biotas such as crab, shrimp, fish, and shellfish).

(3) Option Value (OV)

The option value $(\mathrm{OV})$ is the value that shows the willingness of an individual to pay for the preservation of resources for future use (Barton, 1994). The benefit value of this option is approached by referring to the biodiversity value of the mangrove forest, which is US $\$ 1,500$ per $\mathrm{km} 2$ or US\$ 15 per ha per year. This value is the value of the biodiversity in Bintuni Bay, Irian Jaya, and is used by experts to estimate the biodiversity value of mangrove forests in Indonesia if the condition is ecologically important and is maintained relatively naturally (Ruitenbeek, 1992). The benefits of this choice are formulated as follows: 
MP $=\frac{\text { MPBi }}{\text { US \$ } 15 \times \text { Mangrove Area in ha }}$

MPBi $=$ Benefits of biodiversity options

(4) Existence Value (EV)

The existence value (EV) is the benefit felt by the community from the existence of mangrove forests after other benefits are excluded from the analysis. In general, this approach is carried out by interviewing respondents, by asking about their willingness to pay to maintain the environmental assets. This benefit is the economic value of the (physical) existence of the mangrove forest ecosystem, and is formulated as follows:

$M E=\sum_{i}^{n}(M E i / n)$

MEi $=$ Existence value of respondent $i$.

$\mathrm{n} \quad=$ The number of samples/respondents.

(5) Bequest Value (BV)

The bequest value (BV) is the economic value derived from the benefits of conserving a resource/ecosystem, for the benefit of doing so or being able to pass them on to future generations.

$\mathrm{MW}=10 \% \times \mathrm{ML}$

Analysis of the total economic value of the mangrove ecosystem can be described as follows: total economic value (NET) / total economic value (TEV) is formulated as:

$\mathrm{NET}=\mathrm{NML}+\mathrm{NMTL}+\mathrm{NMP}+$ $\mathrm{NME}+\mathrm{NMW}, \ldots$

\section{RESULT AND DISCUSSION}

\section{Direct Use Value}

\subsection{Direct Use Value for Businessmen}

The results showed that several activities or jobs utilized or intersected with the mangrove ecosystem, namely fishermen, farmers, processors, tourism managers, and mangrove nurseries. Most of the people's main livelihood is as fishermen and fish farmers. Jobs as fishermen and fish farmers, of course, have a lot to do with mangrove ecosystems. For fishermen, mangroves are a place for small fish to take shelter before they reach their adult size, while for farmers they serve as protection from the waves.

The direct use value in 10 coastal villages in Semarang City consists of five types of work, namely fishermen, farmers, processors, tourism managers, and mangrove nurseries. The number of fishermen in the 10 urban villages, based on 2019 BPS data, is 660. From the 660 fishermen, the monthly income is IDR $1,821,600,000$, so in one year the income is IDR $21,859,200,000$. The farmer's income per harvest (on average every five months) of 694 farmers is IDR $7,460,500,000$, so the annual income is IDR $14,921,000,000$.

The income of 34 processors per month is IDR $102,573,750$, so the annual income is IDR $1,230,885,000$. A job as a tour manager for three people for one year is IDR $80,000,000$. The monthly income of three mangrove nurseries on the coast of Semarang City is IDR 56,250,000, so in one year it is IDR $675,000,000$. The calculation of direct use value in 10 coastal villages in Semarang City can be seen in Table 2 below.

\subsection{Economic Value of Fauna Diversity}

In addition to the direct value of activities that intersect mangroves, in-field observations and animal diversity are also found in the coastal areas of Semarang City. A total of 87 bird species were found in field observations, 72 of which were, according to the IUCN Red List, of least concern (LC), 4 nearly threatened (NT) species, 1 endangered (EN) species, 1 vulnerable (VU) species, the remaining 9 species were not included in the list. 
Table 2. Direct Use Value in 10 Coastal Districts of Semarang City.

\begin{tabular}{|c|c|c|c|c|c|c|}
\hline \multirow{2}{*}{ No. } & \multirow{2}{*}{ Jobs } & \multirow{2}{*}{ Person } & \multicolumn{3}{|c|}{ Total Income (each person) } & \multirow{2}{*}{ Total Economy } \\
\hline & & & Monthly & Harvest & Annually & \\
\hline 1. & Fishermen & 660 & $2,760,000$ & \multirow{4}{*}{$10,750,000$} & & $21,859,200,000$ \\
\hline 2. & Fish Farmers & 694 & & & & $14,921,000,000$ \\
\hline 3. & Processors & 34 & $3,016,875$ & & \multirow{3}{*}{$26,666,667$} & $1,230,885,000$ \\
\hline 4. & Tourism Managers & 3 & & & & $80,000,000$ \\
\hline 5. & Mangrove Nurseries & 3 & $18,750,000$ & & & $675,000,000$ \\
\hline & Total & 1,394 & & & & $38,766,085,000$ \\
\hline
\end{tabular}

Source: Primary data, processed, 2020.

In addition to the discovery of birds, nine species of mammals were also found in the coastal areas of Semarang City. According to the IUCN red list, 8 mammal species are included as the least concern (LC) and 1 as vulnerable (VU) species. Herpetofauna species were also found during the observation of the coastal areas of Semarang City. A total of 22 species were found, 16 of which were included as being of least concern (LC) while the rest were classified as near evaluated (NE). The calculation of the economic value of the fauna's diversity can be seen in Table 3 below.

Table 3. Economic Value of Fauna's Diversity.

\begin{tabular}{|c|c|c|c|}
\hline \multirow{2}{*}{ No. Description } & \multicolumn{2}{|c|}{ Amount } & \multirow{2}{*}{$\begin{array}{c}\text { Nilai } \\
\text { Ekonomi }\end{array}$} \\
\hline & Species & Individual & \\
\hline 1 Birds & 87 & 6,279 & $\overline{1,655,874,000}$ \\
\hline 2 Mammalia & 9 & 74 & $1,110,000$ \\
\hline 3 Herpetofauna & 22 & 374 & $1,147,250$ \\
\hline Total & 118 & 3,550 & $1,658,131,250$ \\
\hline
\end{tabular}

Source: Primary data, processed, 2020.

A total of 87 species of Birds are known to be of economic value and can be traded. Determining the valuation value for the birds was done using the price set by the Regulation of the Minister of Trade of the Republic of Indonesia number 03 / M-DAG / PER / 1/2014 and also the value of the birds in the market; the economic value of the bird's diversity is IDR $1,655,874,000$. A total of nine mammal species have economic value and can be bought and sold, such as, Felis domestica, Herpestes- javanicus, Amblonyx cinerea, Bandicota bengalensis, Suncus murinus, Rattus tiomanicus, Cynopterusbrachyotis, Macoglossussobrinus, Hipposideros sp. Determination of the valuation value for the mammals was done using the price set by the Regulation of the Minister of Trade of the Republic of Indonesia number 03 / M-DAG / PER / 1/2014, the economic value of mammals being IDR 1,110,000. Various Herpetofauna species were found, such as Varanus salvator, Calotes versicolor, Gehyra mutilate, Hemidactylus frenatus, Hemidactylus platyurus, Eutropismultifasciata, Takydromussexlineatus, Duttaphrynusmelanosticus, Fejervaryacancrivora, Eutropismultifasciata, Xenopeltis unicolor, Ahaetullaprasina, Cerberus rynchops, Dendrelaphis pictus, Homalopsisbuccata, Enhydrisplumbea, Enhydrisenhydris. In the observation, Birds, Mammalia, and Herpetofauna have economic value and can be traded, for example the economic value of Herpetofauna is IDR $1,147,250$.

\section{Economic Value of Plant Diversity}

In general, the economic value of the plant diversity on the coast of Semarang City is presented in Table 4.

\section{Value of Mangrove Benefits for Building Wood}

Table 5 shows the value of mangrove wood benefits in 10 villages in the coastal areas of Semarang City. 
Table 4. Economic Value of Plant Diversity.

\begin{tabular}{cllrr}
\hline No. & \multicolumn{1}{c}{ Benefit } & Amount & \multicolumn{1}{c}{ Price } & Total Economy \\
\hline 1 & Building Wood & $65,979 \mathrm{~m}^{3}$ & 800,000 & $1,187,630,518$ \\
2 & Firewood & 15,760 bunches & 8,000 & $126,081,600$ \\
3 & Mangrove Seeds & $4,202,720$ seeds & 1,500 & $4,728,060,000$ \\
4 & Jeruju leaves & $10,275.65 \mathrm{~kg}$ & 20,000 & $205,513,008$ \\
\hline & & & $\mathbf{6 , 2 4 7 , 2 8 5 , 1 2 6}$ \\
\hline
\end{tabular}

Source: Primary data, processed, 2020.

Table 5. Value of Mangrove Wood.

\begin{tabular}{clr}
\hline No. & Description & Amount \\
\hline 1 & Mangrove Forest Area (hectares) & 262.67 \\
2 & Potential Commercial Timber (m3/ha/year) & 251.19 \\
3 & Timber Price (Rp/m3) & 800,000 \\
4 & Value of Mangrove Wood (Rp/year) & $1,187,630,518$ \\
\hline \multicolumn{2}{l}{ Source: Primary data, processed, 2020. }
\end{tabular}

Calculations using stand volume analysis were done, which involved measuring the diameter of the logs and also the height of the mangrove trees. The potential yield of mangrove wood volume was calculated to be $251.19 \mathrm{~m} 3$ / ha/year. The price of mangrove wood is 800,000 per $\mathrm{m} 3$, so the net benefit value of mangrove wood is IDR $1,187,630,518$ per year.

\section{Value of Mangrove Benefits for Firewood}

In Indonesia, mangrove wood is generally used by coastal communities as fuel for cooking because it can be obtained easily and at low prices. Details of the benefit value of mangroves for firewood are presented in Table 6. Referring to the research of Prayogi et. al., (2017), assuming that one hectare of mangrove can produce 60 bunches of firewood per year, so the mangrove forests on the coast of Semarang City have the potential for 15,760 bunches/year. The potential benefit value of the mangroves as fuel, with the assumption of IDR 8,000 / bunch as firewood, the area of mangrove forest in the 10 coastal villages of Semarang City is 262.67 ha, it is estimated that the benefits value of mangroves as firewood in the coastal area of Semarang City is IDR $126,081,600$ per year.

\section{Value of Mangrove Fruit and JerujuLeaves}

Another product of the mangrove ecosystem is the mangrove propagules/fruit, which are used as ready-to-sell seeds and jeruju leaves. Details of the benefits of mangrove fruit and jeruju leaves are presented in Tables 7 and 8 .

Based on Prayogi et. al., (2017), one hectare of mangrove can produce 16,000 seedlings per year, assuming that $25 \%$ of the seeds are replanted, so the number of seeds that can be traded is 12,000 seeds/ha/year. Furthermore, the benefit value of mangrove seedlings in the northern coastal area of Semarang City is IDR $4,728,060,000$ per year.

Table 6. Value of Mangrove Benefits for Firewood.

\begin{tabular}{clr}
\hline No. & Description & Amount \\
\hline 1 & Mangrove Forest Area (hectares) & 262.67 \\
2 & Firewood Productivity (bunch/ha/year) & 60 \\
3 & Wood Price (IDR / bunch) & 8,000 \\
4 & Value of Firewood (IDR / year) & $126,081,600$ \\
\hline
\end{tabular}


Table 7. Value of Mangrove Fruit.

\begin{tabular}{clr}
\hline No. & Description & Amount \\
\hline 1 & Mangrove Forest Area (hectares) & 262.67 \\
2 & The productivity of Seeds (seeds/ha/year) & 12,000 \\
3 & Seed Price (IDR / Seed) & 1,500 \\
4 & Value of Mangrove Fruit (IDR / year) & $4,728,060,000$ \\
\hline Source: & Primary data, processed, 2020.
\end{tabular}

Table 8. Value of Jeruju Leaves.

\begin{tabular}{clr}
\hline No. & Description & Amount \\
\hline 1 & Mangrove Forest Area (hectares) & 262.67 \\
2 & Productivity (kg / ha / year) & 39.12 \\
3 & Price of crackers (IDR / kg) & 20,000 \\
4 & Value of Jeruju Leaves (IDR / year) & $205,513,008$ \\
\hline Source: & Primary data, processed, 2020.
\end{tabular}

Jeruju leaf (Acanthus ilicifolius) is a mangrove forest product that is generally used by the community as the raw material for making crackers. According to Ariftia et. al., (2014), one hectare of mangrove forest can supply enough jeruju leaves to make 39.12 $\mathrm{kg} / \mathrm{ha} /$ year of crackers. If multiplied by the price of crackers per $\mathrm{kg}$ of IDR 8,000, then the benefits from jeruju leaves are IDR 205,513,008 per year.

\section{Indirect Use Value}

In general, the indirect use value of the mangrove ecosystem on the coast of Semarang City is presented in Table 9. The explanation of each of these benefits is presented in points 4.2.1 to 4.2.3.

\subsection{Benefit Value as Carbon Storage}

According to Hamrick \& Goldstein (2016), the selling price of carbon is only in the range of US
$\$ 4.6$ to $\$ 10$ per tonne of carbon. The total amount of upper carbon (tree biomass) in the 10 coastal villages of Semarang City is 38,165.95 tonnes, so it can be estimated that the economic value of carbon in mangrove stands is IDR $5,216,793,024$ at an exchange rate of US $\$ 1$ to IDR 13,668.71 (February 18, 2020).

In contrast to the above, and based on the measurement results, the total quantity of sediment carbon is $210,109.73$ tons, so it can be estimated that the economic value of carbon in the mangrove's sediment is IDR 28,719,289,675 at an exchange rate of US \$ 1 of IDR 13,668.71 (February 18, 2020).

\subsection{Benefit Value as Pollutant Absorbent}

Research conducted by Mukherjee et. al., (2014) shows that the value of mangrove ecosystem services in reducing pollutants is an average of US $\$ 7,859.92$ / ha per year. This value is the value of United States dollar in 2007, which if

Tabel 9. Indirect Use Value

\begin{tabular}{clrr}
\hline No. & Benefits & Amount & Total Economy \\
\hline 1 & Mangrove Carbon & $38,165.95$ tons & $5,216,793,024$ \\
2 & Sediment Carbon & $210,109.73$ tons & $28,719,289,675$ \\
3 & Pollutant Absorbent & $107,434,967 /$ ha/year & $28,219,942,809$ \\
4 & Flood Prevention Rob & 865.82 ha & $34,519,197,630$ \\
\hline & Total & & $\mathbf{9 6 , 6 3 7 , 4 2 0 , 9 5 0}$ \\
\hline
\end{tabular}

Source: Primary data, processed, 2020. 
converted into rupiah is around IDR 70,739,280 /hectare in one year (1 US \$ in 2007 was equivalent to IDR 9,000). This value is the average value obtained from global research into mangrove ecosystem services. Considering the value of money, which is influenced by time (time value of money), then in 2020 the valuation value of ecosystem services in the coastal area of Semarang City, in terms of pollutant absorption, is estimated at IDR 107,434,967.1 / hectare per year. Based on this assumption, the value for the valuation of ecosystem services in the absorption of pollutants by mangroves in Semarang City is IDR 28,219,942,809 / year for an area of 262.67 ha.

\subsection{Value of Benefits as a Rob flood prevention}

Other benefits obtained include protection services against tidal flooding. Semarang is the capital city of Central Java, and has experienced annual flooding caused by rising sea levels followed by land subsidence, so that currently tidal flooding has entered residential areas. This condition forces the affected coastal communities to adapt to cope with tidal flooding independently. It is not only people who are directly affected by it but also other productive areas, such as rice fields, ponds, and industrial areas. This adaptation activity of course requires a fee; the amount depends on what activities are carried out, including raising the soil surface and making APO for a certain area. In contrast to other areas, tidal flooding in paddy fields and ponds has resulted in a decrease in the productivity value of the harvest obtained, because the management process is hampered and not optimal.

Calculation of the value of losses due to tidal flooding is done using preliminary data on how wide the affected area is and what areas are affected. The overlay results of Scenario 4 rob flood inundation map with a map of the coastal area of Semarang City can be seen in Table 10 .

Table 10. Area Affected by Rob Flood in 10 Sub-districts Target of 2020.

\begin{tabular}{|c|c|c|c|}
\hline No & Sub District & Area & Hectares \\
\hline \multirow[t]{2}{*}{1} & Mangkang Kulon & Pond & $\overline{50.46}$ \\
\hline & & Settlement & 2.52 \\
\hline \multirow[t]{2}{*}{2} & Mangunharjo & Settlement & 1.91 \\
\hline & & Pond & 151.29 \\
\hline \multirow[t]{3}{*}{3} & Mangkang Wetan & Rice fields & 28.64 \\
\hline & & Settlement & 4.58 \\
\hline & & Pond & 107.58 \\
\hline \multirow[t]{3}{*}{4} & Randugarut & Settlement & 2.66 \\
\hline & & Industrial area & 46.15 \\
\hline & & Pond & 72.22 \\
\hline 5 & Karanganyar & Pond & 62.10 \\
\hline 6 & Tugurejo & Pond & 111.74 \\
\hline 7 & Tambakharjo & Pond & 101.71 \\
\hline \multirow{2}{*}{8} & Terboyo Kulon & Settlement & 2.08 \\
\hline & & Pond & 70.20 \\
\hline \multirow[t]{2}{*}{9} & Terboyo Wetan & Pond & 49.62 \\
\hline & & Settlement & 0.13 \\
\hline \multirow[t]{5}{*}{10} & Trimulyo & Settlement & 0.22 \\
\hline & TOTAL & Settlement & 14.10 \\
\hline & & Pond & 776.93 \\
\hline & & Rice fields & 28.64 \\
\hline & & Industrial area & 46.15 \\
\hline
\end{tabular}

Source: Primary data, processed, 2020. 
The calculation of the value of settlement losses is based on the results of the research by Karunia (2017), which states that the average economic loss value for each household is IDR 2,340,563 / household/year. Then, to find out the total number of affected households (heads of households), it is assumed that each household has a settlement with the current standard housing area, which is $60 \mathrm{~m} 2$. Hence the total number of households affected by tidal flooding covering an area of 14.1 ha, is 2,350 households. Then the total number of affected households is multiplied by the average value of the economic losses for each household, resulting in a total loss value of IDR 5,500,323,050 / year (Table 19).

The calculation for the pond's area (Table 11), using productivity data from BPS (2019), is 2.15 tonnes/ha/year. The pond's management allow the harvesting of milkfish three times a year (YKAN, 2019). In Scenario 4, it is explained that in one year, there will be two tidal floods. The assumption is that during one year there is one crop failure. Thus, the annual crop failure value yields a figure of 0.72 tonnes/year. Furthermore, by referring to the latest average price of fresh milkfish in Semarang City, which is IDR $22,980 / \mathrm{kg}$, with the affected pond area of $776.93 \mathrm{ha}$, the total loss of economic value is IDR $12,854,773,000$.

Furthermore, for the calculation of the affected rice field area (Table 11), it is almost the same as the calculation for the pond area. The data used is in the form of rice yield productivity in Semarang City, which was as much as 5.26 tonnes/ha in 2019. In Scenario 4, it is explained that in one year, there will be two tidal floods. So the assumption is that if you can harvest twice a year, then because of the tidal flood there will be one crop failure. The value of crop failure yields a figure of 2.63 tonnes/ ha/year. Referring to the current market price of rice (yields) in the city of Semarang, which is IDR $4,200 / \mathrm{kg}$, and the affected area of rice fields is 28.64 ha, the total loss of economic value is IDR $316,343,120$.

For the calculation of industrial areas (Table 11), the approach used is in the form of building APO activities to prevent tidal flooding. Thus, the calculation's assumption is to calculate the total length of the affected industrial area's shoreline. The total area of the industrial area is $46.15 \mathrm{ha}$, and the length of the affected coastline is $3.71 \mathrm{~km}$. Furthermore, the cost needed to build an APO refers to the APO development program in Demak, run by the Ministry of Marine Affairs and Fisheries (KKP). Using concrete to build an APO, the cost is IDR 4,271,633 / meter (KKP, 2012). So, the total cost of APO development in the industrial estates is obtained, namely IDR $15,847,758,430$. So, the total economic value of tidal flood prevention on the coast of Semarang City is IDR 34,519,197,630.

Tabel 11. Economic Value of Flood Prevention Rob.

\begin{tabular}{rlrr}
\hline No & \multicolumn{1}{c}{ Area Affected } & Hectares & \multicolumn{1}{c}{ Total Economy } \\
\hline 1 & Settlement & 14.10 & $5,500,323,050$ \\
2 & Pond & 776.93 & $12,854,773,000$ \\
3 & Rice fields & 28.64 & $316,343,120$ \\
4 & Industrial area & 46.15 & $15,847,758,430$ \\
\hline \multicolumn{2}{r}{ TOTAL } & $\mathbf{8 6 5 . 8 2}$ & $\mathbf{3 4 , 5 1 9 , 1 9 7 , 6 3 0}$ \\
\hline
\end{tabular}

Source: Primary data, processed, 2020. 


\section{Option Value}

To get the benefits of biodiversity, the biodiversity value of mangroves in the northern coastal area of Semarang City is multiplied by an average value of US $\$ 1,500 / \mathrm{km} 2$ / year or US \$ 15 / ha/year (Ruitenbeek, 1992). The total area of mangrove forest in 10 urban villages in the northern coastal area of Semarang City is 262.67 ha. If this is multiplied by the biodiversity value of mangrove forests in Indonesia, of US \$ 15 / ha/year, the selected value of mangrove forest ecosystems will reach IDR 53,855,400.84 per year at an exchange rate of IDR 13,668.71 (February 18, 2020).

\section{Existence Value (Willingness to Pay)}

In this study, the contingent valuation method (CVM) was carried out to obtain the willingness to pay (WTP) value, as presented in Table 12 . The formation of a hypothetical market using CVM for WTP's determination techniques involves the replacement of the entrance ticket price from the ecotourism concept by looking at the mangrove ecosystem as a tourist attraction and a habitat for protected birds. The technique used to obtain the bid value in this study is the open-ended question method approach.

From all of the respondents, 85 people were willing to accept/give the value of the offer so that the BID value collected was IDR 1,240,500.
The average WTP value of the 85 respondents was IDR 14,594, which was rounded up to IDR 14,600 . With the total population of the 10 urban villages that are the object of the research totaling 38,925 residents, the total willingness to pay (TWTP) for ecotourism activities in this study is IDR 568,305,000 per year.

\section{Bequest Value}

This value is the economic value obtained from the benefits of conserving resources/ecosystems for the benefit of future generations. The value of inheritance benefits are obtained from $10 \%$ of the value of direct benefits (IDR 46,512,651,376 / economic value of business actors, the value of diversity of fauna and plants), which is IDR $4,651,265,138$ per year.

\section{Total Economic Value of Mangrove Ecosystem Services}

According to the results of the calculations (Table 13), the total economic value of mangrove ecosystem services in the coastal area of Semarang City was IDR 148,635,962,910 per year with a total study area of $1,128.49$ ha, which includes residential areas, ponds, rice fields, industrial areas, and mangroves. Based on the data, the average mangrove ecosystem services on the coast of Semarang City are equivalent to IDR $131,712,255$ per ha of land.

Table 121. Willingness to Pay in 10 Coastal Villages in Semarang City.

\begin{tabular}{|c|c|c|c|c|c|c|c|}
\hline No & Description & Respondents & $\begin{array}{c}\text { BID } \\
\text { Accepted }\end{array}$ & $\begin{array}{c}\text { BID } \\
\text { Amount }\end{array}$ & $\begin{array}{l}\text { Average } \\
\text { WTP }\end{array}$ & Population & Total WTP \\
\hline 1. & Fisherman & 47 & 42 & 428,500 & \multirow{6}{*}{14,600} & \multirow{6}{*}{38,925} & \multirow{6}{*}{$568,305,000$} \\
\hline 2. & Farmers & 22 & 21 & 382,000 & & & \\
\hline 3. & Processor & 16 & 16 & 225,000 & & & \\
\hline 4. & Tourism Manager & 3 & 3 & 160,000 & & & \\
\hline 5. & Mangrove Nursery & 3 & 3 & 45,000 & & & \\
\hline & Total & 91 & 85 & $1,240,500$ & & & \\
\hline
\end{tabular}

Source: Primary data, processed, 2020. 
Table 13. Total Economic Value of Mangrove Ecosystem Services in the Coastal Zone of Semarang City.

\begin{tabular}{|c|c|c|c|}
\hline \multirow{2}{*}{$\begin{array}{c}\text { No. } \\
1\end{array}$} & \multirow{2}{*}{$\begin{array}{ll} & \text { Benefits } \\
\text { Direct Use Value } & \end{array}$} & \multicolumn{2}{|c|}{ Economic Value (Rupiah) } \\
\hline & & & $46,671,501,376$ \\
\hline & - Businessmen & $38,766,085,000$ & \\
\hline & - $\quad$ Fauna diversity & $1,658,131,250$ & \\
\hline & - Plant diversity & $6,247,285,126$ & \\
\hline 2 & Indirect Use Value & & $96,637,420,950$ \\
\hline & - - Upper mangrove biomass carbon & $5,216,793,024$ & \\
\hline & - $\quad$ - Sediment carbon & $28,719,289,675$ & \\
\hline & - $\quad$ - Absorbing pollutants & $28,182,140,620$ & \\
\hline & - $\quad$ - Rob flood prevention & $34,519,197,630$ & \\
\hline 3 & Option Value (mangrove forest area) & & $53,855,400$ \\
\hline 4 & Existence Value (WTP ecotourism) & & $568,305,000$ \\
\hline 5 & Bequest Value (10\% direct benefit) & & $4,667,150,138$ \\
\hline & Total & & $148,635,962,910$ \\
\hline
\end{tabular}

Source: Primary data, processed, 2020.

\section{CONCLUSION AND SUGGESTION}

The direct use value comes from fishermen, farmers, processors, tourism managers, mangrove nurseries, diversity of fauna, and plants. The indirect use value is obtained by carbon in the upper mangrove biomass, sediment carbon, absorbing pollutants, and preventing flooding. The option value is obtained from the area of the mangrove forest. The existence value is obtained by using the contingent valuation method by asking the willingness to pay. The bequest value is obtained from $10 \%$ of the direct use value.

The total economic value (TEV) in the northern coastal area of Semarang City is IDR $148,635,962,910$ per year for the total study area of 1,128.49 ha, which includes residential areas, ponds, rice fields, industrial areas, and mangroves. This value is an estimate to get an overview of the mangrove ecosystem services on the coast of Semarang City. In this study we only calculate the data available at the time of the study and cannot change the government's decisions regarding mangrove areas.

\section{REFERENCE}

Ariftia, R. I., Qurniati, R., \& Herwanti, S. (2014). Nilai ekonomi total hutan mangrove desa Margasari kecamatan Labuhan Maringgai kabupaten Lampung Timur. Jurnal Sylva Lestari, 2(3), 19-28.

Badan Pusat Statistik Kota Semarang. (2016). Kecamatan Genuk Dalam Angka 2017. . KecamatanTugu Dalam Angka 2017.

. (2018). Kecamatan Genuk Dalam Angka 2018.

Kecamatan Semarang Barat Dalam Angka 2018.

. (2019). Kecamatan Genuk Dalam Angka 2019.

Kecamatan Semarang Barat Dalam Angka 2019.

. Kecamatan Tugu Dalam Angka 2019.

Barton, D. N. (1994). Economic factors and valuation of tropical coastal resources.

Brower, J. E., Zar, J. H., \& Von Ende, C. N. (1998). Field and laboratory methods for general ecology.

Cintron, G., \& Schaeffer Novelli, Y. (1984). Methods for studying mangrove structure. Monographs on oceanographic methodology, 8, 91-113. 
Ciriacy-Wantrup, S. V. (1968). Resource conservation: economics and policies. Univ of California Press.

Davis, R. K. (1963). Recreation planning as an economic problem. Nat. Resources J., 3, 239.

Dharmawan, I. W. E., \& Pramudji, S. (2017). Panduan Pemantauan Komunitas Mangrove. Pusat Penelitian Oseanografi LIPI. Jakarta.

Dinas Kelautan dan Perikanan Jawa Tengah. (2016). Kerangka Acuan Kerja (KAK) Rehabilitasi dan Konservasi Sumberdaya Kelautan dan Perikanan Tahun 2016.

Dinas Kelautan dan Perikanan Kota Semarang. 2010. Laporan Akhir Penyusunan Pemetaan Potensi Kerusakan dan Model Rehabilitasi Kawasan Pesisir Kota Semarang.

2010. Kota Semarang Dalam Angka. Semarang. Pemerintah Kota Semarang. 2014. Kota Semarang Dalam Angka. Semarang. Pemerintah Kota Semarang.

2015. Perikanan Dalam Angka. Semarang. Pemerintah Kota Semarang.

Dinas Kelautan Perikanan Provinsi Jawa Tengah. 2013. Kota Semarang Dalam Angka. Semarang. Pemerintah Kota Semarang. Direktorat Pesisir dan Lautan Direktorat Jenderal Kelautan, Pesisir dan Pulau-pulau Kecil Departemen Kelautan dan Perikanan. 2007. Dalam Panduan Lokakarya Nasional Pengelolaan Jasa Kelautan dan Perikanan. Hotel Bumikarsa Jakarta, tanggal $19-20$ Juni 2007.

Duke, N., Nagelkerken, I., Agardy, T., Wells, S., $\&$ Van Lavieren, H. (2014). The importance of mangroves to people: A call to action. United Nations Environment Programme World Conservation Monitoring Centre (UNEP-WCMC).

Eggleston, S., Buendia, L., Miwa, K., Ngara, T., \& Tanabe, K. (Eds.). (2006). 2006 IPCC guidelines for national greenhouse gas inventories (Vol. 5). Hayama, Japan: Institute for Global Environmental Strategies.

Fajrin, F. M., Muskananfola, M. R., \& Hendrarto, B. (2016). Karakteristik Abrasi dan Pengaruhnyaterhadap Masyarakat di Pesisir Semarang Barat. Journal of Management of Aquatic Resources, 5(2), 43-50.
Fauzi, A. (2004). Ekonomi sumber daya alam dan lingkungan: Teori dan aplikasi. Gramedia Pustaka Utama.

Freeman III, A. M., Herriges, J. A., \& Kling, C. L. (2014). The measurement of environmental and resource values: theory and methods. Routledge.

Hamrick, K., \& Goldstein, A. (2016). Raising ambition: State of the voluntary carbon markets 2016. Ecosystem Marketplace Washington DC http://www. forest-trends. org/documents/files/doc_5242. pdf.

Hanley, N., \& Spash, C. (1996). Cost benefit analysis and the environment.

Indonesia, S. N. (2011). Pengukuran dan penghitungan cadangan karbon-Pengukuran lapangan untuk penaksiran cadangan karbon hutan (ground based forest carbon accounting). Badan Standarisasi Indonesia. SNI, 7724, 2011.

Islam, L. J. F., Prasetyo, Y., \& Sudarsono, B. (2017). Analisis Penurunan Muka Tanah (Land Subsidence) Kota Semarang Menggunakan Citra Sentinel-1 Berdasarkan Metode Din SAR pada Perangkat Lunak SNAP. Jurnal Geodesi Undip, 6(2), 29-36.

IUCN \& Mangrove Action Project. (2007). Kebijakan Untuk MANGROVE. mangroveactionproject.org/

Karunia, I. (2017). Estimasi Kerugian Ekonomi Masyarakat Akibat Banjir Rob di Pemukiman Kecamatan Genuk Kota Semarang.

Kauffman, J. B., \& Donato, D. C. (2012). Protocols for the measurement, monitoring and reporting of structure, biomass, and carbon stocks in mangrove forests (pp. 50p). Bogor, Indonesia: CIFOR.

Kementerian Kehutanan. 2012. Data dan Informasi Mangrove Sempadan Pantai. Direktorat Jenderal Bina Pengelolaan DAS dan Perhutanan Nasional. Jakarta.

Kementerian Perencanaan Pembangunan Nasional/Badan Perencanaan Pembangunan Nasional Republik Indonesia. 2019. Rancangan Teknokratik. Rencana Pembangunan Jangka Menengah Nasional 2020-2024.

Kitamura, S., Anwar, C., Chaniago, A., \& Baba, S. (1997). Handbook of Mangroves in Indonesia; Bali \& Lombok. International society for mangrove ecosystem. Denpasar, 119. 
Kota Semarang Dalam Angka. 2017. Diterbitkan oleh Badan Pusat Statistik Kota Semarang. Publikasi ini berisi data dan informasi mengenai kondisi daerah Kota Semarang dari berbagai aspek/sektor utama nya pada tahun 2016.

Kusrini, M. D., Ul-Hasanah, A. U., \& Endarwin, W. (2008). Pengenalan HerpetofaunaDisampaikan Pada Pekan Ilmiah Kehutanan Nasional. Institut Pertanian Bogor. Bogor.

Miladan, N. (2009). Kajian kerentanan wilayah pesisir Kota Semarang terhadapperubahan iklim.

Mukherjee, N., Sutherland, W. J., Dicks, L., Huge, J., Koedam, N., \& Dahdouh-Guebas, F. (2014). Ecosystem service valuations of mangrove ecosystems to inform decision making and future valuation exercises. PloS one, 9(9), e107706.

Prayogi, H., Wijayanto, D., \& Raysina, N. (2017). Kajian valuasi ekonomi hutan mangrove di Desa Pantai Mekar, Kecamatan Muara Gembong, Kabupaten Bekasi.

Ruitenbeek, H. J. (1992). Mangrove management: An economic analysis of management options with a focus on Bintuni Bay, Irian Jaya. Menteri Negara Kependudukan dan Lingkungan Hidup.
Safitri, F., Suryanti, S., \& Febrianto, S. (2019). Analisis Perubahan Garis Pantai Akibat Erosi di Pesisir Kota Semarang. GEOMATIKA, 25(1), 37-46.

SNI. 2011. Pengukuran dan Penghitungan Cadangan Karbon-Pengukuran Lapangan Untuk Penaksiran Cadangan Karbon Hutan (ground based forest carbon accounting). Badan Standarisasi Nasional (BSN). Jakarta.

Suripin, S., \& Syafrudin, S. (2015). Pengaruh land subsidence terhadap genangan banjir dan rob di Semarang Timur. Media Komunikasi Teknik Sipil, 21(1), 1-12.

Suzana, B. O. L., Timban, J., Kaunang, R., \& Ahmad, F. (2011). Valuasi Ekonomi Sumberdaya Hutan Mangrove Di Desa Palaes Kecamatan Likupang Barat Kabupaten Minahasa Utara. Agri-Sosioekonomi, 7(2), 29-38.

Tomlison, P. B. (1986). The botany of mangrove. Cambridge University Prees.

WWF-US Climate Adaptation Program. (2009). Building Mangrove Resilience to Climate Change. https://www.worldwildlife.org/

YKAN. 2019. Pemetaan Partisipatif di Kawasan Pesisir Kota Semarang Tahun 2019. Mangrove Ecosystem Restorarion Alliance (MERA). Jakarta. 